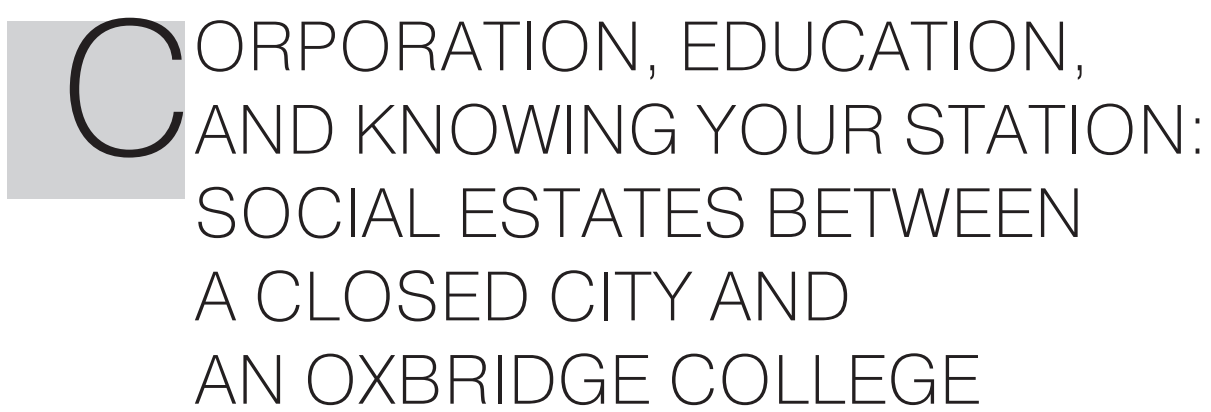

\title{
Dominic Martin
}

Dominic Martin, Centre on Migration, Policy \& Society (COMPAS), School of Anthropology \& Museum Ethnography, University of Oxford. Address for correspondence: University of Oxford, COMPAS, School of Anthropology, 58 Banbury Road, Oxford, OX2 60S, UK.dominic.martin@compas.ox.ac.uk.

This article is based on research conducted with the generous support provided by the Economic and Social Research Council (UK), the MacMillan Center at Yale University (USA), and the Higher School of Economics in Saint Petersburg (Russia). I am grateful to Caroline Benson-Hall, Caroline Humphrey, and Doug Rogers. I also wish to thank two anonymous reviewers for their helpful suggestions.

The rise of contemporary corporations in Vladimir Putin's Russia has coincided with a revival of soslovie, a form of social segmentation based on "estates" rather than on clan, tribal, or class distinctions. Theorizing distinction in societies, Pierre Bourdieu emphasized the importance of the role played by education. He especially underlined distance from economic necessity as being a characteristic ideal of bourgeois educational aspirations. This article examines two contemporary perspectives on education, both linked by a Russian energy corporation. One is focused on an elite family from Russia based in England, the other on the children of a renascent Old Orthodox group resident in a former "closed" city in Primorski Krai. Deploying theoretical apparatus advanced by Bourdieu, I identify the continuing application of the concept of estates-soslovie-as a means of ordering various functions and strata in society and especially as an engine driving aspects of choice and distinction in the education of young people coming of age at the social and geographic extremities of the aura of a global corporation. In both contexts, a sense of belonging to an estate seems to be at the heart of what is being inculcated. An autoethnographic perspective links an ancient Oxbridge college with the former closed military-industrial city in Russia's Pacific, and the new corporate power elite is imbricated in a global assemblage with a marginal dissenting religious community. Obdurate cultural legacies from Soviet times play a role alongside more recently acquired bourgeois aspirations in this assemblage.

Keywords: Distinction; Corporation; Necessity; Education; Estate; Soslovie

The rise of contemporary corporations in Vladimir Putin's Russia has coincided with a revival, noted by some scholars, of soslovie, a form of social segmentation based on "estates" rather than on clan, tribal, or class distinctions. Theorizing distinction in societies, Pierre Bourdieu has emphasized the importance of the role played by edu- 
cation. He especially underlined distance from economic necessity as being a characteristic ideal of bourgeois educational aspirations. This article examines aspects of the education experienced by two contrasting sibling groups of young Russians, growing up in sharply different economic and geographical circumstances, under the umbrella of a global energy corporation. In both contexts, a sense of belonging to an estate seems to be at the heart of what is being inculcated. I deploy an autoethnographic perspective in order to link the new Russian corporate power elite, specifically a very senior manager in the prototypical energy corporation, with a renascent Old Orthodox religious community, reinforcing the insight that corporations in their multiple complexity are able to "metacoordinate" actions and projects, often while actors are unaware of this reach (Rogers 2015:149). This imbrication brings the ivory towers of 0xbridge and the energy frontier of Russia's Far East together symmetrically onto a plateau of global connection, which in turn makes this narrative an ethnography of a global assemblage brought about by the unintended metacoordinating effects of the Russian corporation, which spill far beyond Russia.

Market values have shaped Russian education over the past decades since the collapse of the USSR impelled the impoverishment and enfeeblement of the once world-respected Soviet system of schooling and scholarship. The same forces that dismembered Soviet education and precipitated the brain drain of Russia-based talent abroad brought to ascendency the elite "New Russians" (Humphrey 2002:177). While they contributed to the implosion of the system in which they themselves had been schooled (and often to a very high degree: many so-called oligarchs obtained advanced kandidat nauk graduate degrees), the post-Soviet Russian rich, as a group widely regarded to have gained its wealth unfairly and illegally, viewed the education of their children as an opportunity to dress the rough reality of their "primitive accumulation" in the more refined garb of stylized privilege. Bourdieu is the theorist of this process by which economic power is transmogrified into cultural and social capabilities. For him the relay between economic power and social/cultural capital is education; the outcome of elite education is "distinction," the unspoken bodily, linguistic, and symbolic hallmarks of social supremacy (Bourdieu 1984). Bourdieu writes that there is a single definitive feature of such distinction: "distance from necessity" (1984:55). This distance from necessity can take many forms: gratuitous luxury, studied ease, or detached and disinterested scholarly reflection. But in each case the necessity from which the measure is taken is ultimately economic, with distinction encoding and mystifying the "power to keep economic necessity at arm's length" (55). Yet, because social need and necessity are social and cultural phenomena to a large extent, they vary across culture (cf. Sahlins 1994) and cannot be reduced to the economic criteria of class. The modalities of "being needed" were profoundly affected by the collapse of the Soviet Union, where economic necessity had been subordinated to the needs of the collective. The forms of distance and distinction from these collective necessities have also changed. One of the arguments of this article is that the necessities which post-Soviets are beholden to or freed from are not simply those of their economic class, but those that are entailed by their place within a hierarchically ranked collective of "estates" called in Russian soslovie. 
This article investigates two ways that education has been used to bring postSoviet youth and children into a particular relationship vis-à-vis estate-based necessity. The needs that education can either distance or foreground are ultimately the market-driven requirements of Russian energy corporations. But these market capitalist imperatives are appropriated by Russians through a quasi-feudal ideology of caste-like distinction. The first half of the article recounts the education of two Russian schoolboys, who are the sons of the new nomenklatura of the Russian energy corporation. Their elite English education is able to instill in them a certain liberality and ease, which are the markers of the bourgeois class, but this distinction is inhabited more as a relative rank that differentiates them from "workers" and servitors. The article's second half relates the educational reforms that have taken place in a city in Primorski Krai in the Russian Pacific, where corporate power has redistributed the incentives for education. Yet, the obdurate cultural legacies of this once "closed" city mean that even these new dynamic market forces are taken up and reconstituted into the stratified hierarchy of estates. The parallels between the two cases lead to some concluding remarks on the relation between corporation and education.

\section{EDUCATING ELITE ENGLISHMEN}

I met Gleb and Katia Gubskii ${ }^{1}$ in the fall of 2015. My then landlady, who was working as their housekeeper/nanny, introduced me as a potential tutor to their two sons. I was finishing my doctoral dissertation in social anthropology at Regent's, an ancient Oxbridge college. At an informal interview at their extremely opulent riverside house, Katia, a dark-haired lady in her late forties invited me to join her and her husband, Gleb, at the table. We switched between Russian and English as we talked about the boys schooling. Having gotten acquainted, the parents introduced me to the boys', Maksim (12) and Misha (10). Misha had an imminent history homework project due, Katia said. Without preparation, I sat down in the study with Misha, a happy-go-lucky blond lad, and together we went through his assignment: It was on World War II and featured an interview with his grandmother, who had been evacuated from Leningrad before the terrible blockade had begun.

An hour passed and we emerged with the project checked. Gleb and Katia were pleased. I tried to return their thanks with a mere ça ne fait rien shrug, but Gleb, a physically imposing man in his midfifties pushed two crisp red notes into my hand: "It's only fair, for work done." Reminiscent of the red Russian 5,000-rouble notes, the red British 50-pound note is also the highest denomination bill of British currency. Never having made a hundred pounds for an hour's work in my life, I eagerly shook Gleb's firm hand and left the Riverhouse giddily with an agreement to return twice a week during term time to help the boys with their humanities subjects. Thereafter I would report to Katia who, as a full-time housewife, was in charge of her boys' education. Gleb, meanwhile, most weekdays was away on business. His work took him between Moscow, Houston, Geneva, and Caracas, where he managed operations for en-

1 All names are pseudonyms. 
ergy conglomerate, Rosgaz. Stuck in the limbo between thesis submission and defense with only the meager remuneration of adjunct teaching to subsist on, for the 2015-16 academic year I was funded, my friends joked, by the "Rosgaz Fellowship."

From Saint Petersburg and born in the 1960s, Gleb graduated from the Economics Faculty of the Leningrad University in the late 1980s. Like his cohort of contemporaries, Dmitrii Medvedev, Aleksei Kudrin, and Aleksei Miller, Gleb made a dual career that shifted between state service and state-aligned hydrocarbon corporation. With homes in both Russia and England, like many successful Russian top managers and chinovniki, he wanted his sons to receive the best English education that money could buy. Yet, Regent's College School was in some ways an unusual choice.

A feeder school to the Regent's College Chapel Choir, it is most famous for its troupe of choristers in white surplices and red soutanes. Regent's College School differs from elite London prep schools not only for its focus on music; it consciously eschews a narrow focus on sheer academic discipline for an informal coeducational experience that provides a liberal, holistic, and humanistic preparation for children to take the English public school Common Entrance exams. The school has an impressive record for placing its pupils in elite schools, such as Harrow, Rugby, and Westminster. The school, founded by Henry VI in 1440, is renowned for cultivating in its pupils an appreciation of the creative and plastic arts, music, painting, and poetry, and the multifaceted education that children get reflects broadly the tradition of its parent institution, Regent's College, as a center of excellence in the performing and plastic arts, the humanities, and social sciences. It is necessary to give a broad outline of the education that this school provided for the Gubskii boys, insofar as it will bring into relief certain similarities and differences with the nexus of education and corporation that I describe in the second half of the article. While I describe the general educational process, I omit any mention of the specific details of the Gubskii's schooling at Regent's, their progress reports, their termly report cards (to which I was privy), their academic successes and struggles-other than to say that they were, each in his own way, remarkable children and a credit to their parents. From our first meeting, their parents were aware that my involvement was motivated at least as much by ethnographic curiosity as by the financial need. They knew I was researching contemporary Russians and included themselves in that category. At the conclusion of my visits Katia usually pointed me in the direction of online articles and YouTube videos that encapsulated her viewpoint, which she was eager for me to see. I take this openness as justification for writing about her and her family for whom admittedly I was an employee, not an embedded ethnographer.

The Gubskii boys were getting a thorough elementary education in literature, history, and in modern languages (French and Chinese), as well as a solid grounding in Classics (Greek and Latin). Much time was taken up with sports (cricket and rugby) as well as piano and painting lessons. While they received comprehensive termly report cards to chart their ongoing progress, at Regent's College School there were far fewer exams and assessments than the frightening trial that the national curriculum inflicts upon pupils in normal English state education (i.e., non-fee-paying) from the age of seven onward. Notwithstanding internal fraternal rivalry for parental approv- 
al, the boys enjoyed school in a relaxed manner without too much pressure in spite of the quite large homework burden. The boys' progress was rapid indeed: they soon spoke in inimitable prep-school accented English. Only to their parents did they speak in Russian, not to each other (and Katia preferred me not to speak to the boys in Russian). Above all, they had already begun to exhibit that modality of relationship to language and culture that Bourdieu identifies as the gold standard of bourgeois distinction: "the self-certainty which accompanies the certainty of possessing cultural legitimacy, and the ease which is the touchstone of excellence" (1984:66).

In her recent impressive study of the Russian elite domiciled in London, Elisabeth Schimpfössl has noted the child-centric educational focus of what she calls the "Russian bourgeoisie." The choices that the first generation of rich Russians have made in the education of their children show a collective anxiety over the social reproduction of their status: "Children and the rituals around them provide their parents with an additional mechanism for reassuring themselves of their social status, and for gaining social distinction" (Schimpfössl 2018:173). Schimpfössl notes how the educational priorities of the Russian elite are gendered, whereby elite educational trajectories are selected for boys, while girls are instead encouraged to pursue more vocational tracks. This was indeed the case for the Gubskiis whose two elder daughters, each more than a decade older than their brothers, had been educated in Russia and Switzerland, not England. In speech and comportment, unlike their brothers, the Gubskii sisters were noticeably Russian; like many elite Russian young women, they pursued careers in fine art sales.

Schimpfössl shows how Russian elite's educational strategies intend to naturalize and legitimize privilege: the elite "wish to be convinced that they deserve their position because of who they are and their superior qualities" (2018:19). As the problem of social reproduction has arisen, the perceived vulgarity of the New Russians has been overtaken by an effort to cultivate a philanthropic ethic of noblesse oblige. Schimpfössl's portrait of rich Russians' attempts to secrete around themselves what might called in the Weberian sense a "theodicy of privilege" (Weber 2001:253) partly chimes with my experience of tutoring an elite Russian corporate family. But collapsing this elite Russian group into the catchall category/class of the "bourgeoisie" loses some of the particularly Russian cultural aspects of this effort to naturalize distinction. I think this cultural difference is brought out by some further aspects of the Gubskiis' worldview and by comparing their schooling to education in a dramatically different ethnographic site context, yet one connected to the Rosgaz family by the subterranean skein of the Russian energy corporation.

\section{THE SOSLOVIE SOCIETY}

Schimpfössl states that because first-generation rich Russians have no ideology to legitimize their privilege and make them seem deserving of their rank, they have fallen back on a myth of the selfless Soviet intelligentsia. Yet, the rich Russians Schimpfössl interviewed avowed that the education of their children draws on models from imperial tradition: "When the child grows up, one can think about a nanny 
who speaks a foreign language. This is an imperial Russian tradition" (Schimpfössl 2018:133).

Having grown up within the relative material lack under Soviet socialism, the Gubskiis were not born into wealth. But as sociologists, historians, and anthropologists have serially pointed out (Fitzpatrick 1993; Getty 2013; Humphrey 2001, 2002), Soviet socialism had rigid forms of internal stratification and hierarchization, often backed by a legally underpinned selective distribution of rights and duties: workers, peasants, state service workers, collective farmers, technological intelligentsia, military, party nomenklatura were neither formally nor substantively equal. The caste of top managers in post-Soviet Russia's state-aligned companies, as well as high-ranking civil servants (chinovniki) in Russia's power ministries (silovye ministerstva), have likewise been compared to the "new aristocracy" of Putin's Russia.

While she had the taste and habits of an average Russian of her generation (listening to Depeche Mode and Robbie Williams, watching Benedict Cumberbatch's Sherlock), Katia exhibited an almost aristocratic concern with her children's education. To my mind her circumspection faintly echoed what Pierre Gilliard (tutor to the last tsarevitch) remembered of Tsarina Alexandra Feodorovna. Both women showed "respect for their teachers by observing that sense of decorum which is the first element of politeness.... When I entered the room I always found the books and notebooks piled neatly in my pupils' places at the table, and I was never kept waiting a moment" (Gilliard 1921:22). The pens and notebooks were always neatly set up when I arrived at the Riverhouse, and Katia would immediately summon the boys from play and command their attention.

The leading theorist of the Russia's "new aristocracy," Simon Kordonskii (2008), argues that a pure class-based approach cannot comprehend the country's rigidly hierarchical social stratification. He proposes, instead, that social elites, such as the top managers at the big state-aligned energy corporations, form a particular estate in a graded and ranked system, which recapitulates the social structure of the nine estates (sosloviia, pl. of soslovie) that stratified the Russian Empire. In imperial Russia each estate, or rank (chin), was not equal before the law but had different obligations and privileges and was punished differently for the same crime. The rationale behind a soslovie, as opposed to a class, is that one receives one's due according to what service one renders to the centralized state, which in turn redistributes resources "fairly" (to each according to their place in a hierarchy wherein everyone intuitively should know his or her place) (see also Humphrey 2012, n.d.).

Kordonskii claims that a law that was passed on state civil service early in Putin's first presidential term, which conferred different rights upon certain levels of state servants, effectively (re)created a series of ranked estates, a system which has only grown in elaboration and internal differentiation since then. The income of each estate is what it receives in correspondence to the service it discharges. What is "fair" to each estate is that it gets its due, usually in the form of "rent" or even "tribute" (dan'). The soslovie system makes talk of corruption irrelevant in Russia, Kordonskii maintains, because rent-seeking and taking kickbacks (otkat) are merely an estate's way of acquiring for its members what they sincerely regard as their "fair 
share." Whether this is a system that has prevailed and thrived under Putin or, indeed, that Putin has emerged and thrived in consequence of its hegemonic grip is a moot question.

In estate thinking, a person is defined not by sheer economic or professional qualifications but, relationally, by whom they serve: "Estates are reproduced in part because people are socialized from birth into the system of mutual service and servicing that is led by the state, either by tradition or policy. They do not conceptualize the organization of the social world in any other way-they not only unreflectively serve someone or another, but they understand their people serving them as a natural phenomenon" (Kordonskii 2008:27). While the market does produce de facto classes, Russians tend not to think of the social world in terms of class. Who one is and where one belongs is fixed by what services you render and to whom, in other words, your estate: the tutor or doctor to the tsar is not the same as one to the ordinary townsfolk. The income that is appropriate to each estate depends not upon hard work or the ability to supply things that the market demands, but upon who you are-the service status of your soslovie - and what thereby you deserve: 20,000 roubles for the high school teacher and 2 million dollars for the top manager. Top estates signal their rank by means of signs such as clothes, watches, and special license plates that protect them from the depredations of lower estates, primarily the security services and traffic police, who feed off the lower ranks.

Katia admitted that she found it perplexing to deal with those in her service, Muriel the nanny/housekeeper and Robin the gardener. Muriel, my landlady, had previously been employed as a warden/guide at Regent's College's world-renowned chapel. She was keen to make friends with the Gubskiis and gifted them Christmas presents. But her attempt to establish reciprocal relations was frostily rebuffed with an immediate return of a 50-pound note. Muriel felt that Katia spoke down to her and lamented her peremptory tone that lacked the constant lubrication of "please," "thank you," and "sorry" that makes up the gestural fabric of upper-middle-class English politesse. Katia confessed in Russian that, though she paid them fairly, she felt her domestic staff were used to taking liberties with their employers and felt more entitled that they deserved.

Katia's wish that English people would simply "know their place" extended into the political sphere. She was very concerned by that year's London mayoral election. Sadiq Khan, left-leaning son of an immigrant Bangladeshi bus driver and the first Muslim to hold high elected office in the UK, had beaten Zac Goldsmith, multimillionaire and intimate of recently sanctioned oligarch Oleg Deripaska. Katia feared that Khan's mayoral victory would embolden certain "elements" who would start to walk with their "heads held high" ("as opposed to bowed and subjected?" I wondered silently) and that London was going to the dogs.

She referred me to the blog of her acquaintance, the brash businessman, Evgenii Chichvarkin. Katia and Gleb remembered Chichvarkin wheeling and dealing through 1990s Saint Petersburg, engaging in PR stunts to promote his mobile phone startup, Ervoset, the success of which would make him one of Russia's youngest self-made multimillionaires. A brush with Putin's security services later, however, forced Chich- 
varkin to flee to London where-entrepreneurial spirit undented-he set up the city's coolest premier retailer of expensive wine and spirits, Hedonism. Chichvarkin spoke for many rich Russians when he expressed public alarm at the election of Sadiq Khan. In his blog Chichvarkin complained of his exasperation at "lazy" and entitled English workers, with their constant tea breaks and tabloid newspaper reading. He stated more baldly what Katia implied in more euphemized terms: he wished London would become like Dubai (Katia and Gleb's favored holiday destination), where society was divided rigidly into castes of servants and the served, where worker discipline was upheld by the omnipresent threat of on-the-spot dismissal and its corollary, ejection from the country.

The Gubskiis, like Chichvarkin, found it inconvenient that their British servants had rights supposedly enshrined in law. A month after her trial period had elapsed, Muriel asked Katia for her employment contract only for Katia to indefinitely stall this legally obligatory step. Ten months later, Katia summarily fired both Muriel and Robin the gardener for "talking back." In response to Muriel's perceived defense of and siding with the gardener in a dispute over an unmowed lawn, Katia merely commanded her nanny/housekeeper "Go!" pointing to the Riverhouse door.

Failing to show solidarity with my fellow employees, I continued to work for the Gubskiis, in whom I increasingly discerned the features of a soslovie mentality. This was evident in how Katia and Gleb related the summary disposal of their domestic staff and its consequences, as well as why they kept me on: It would be futile for Muriel to make legal recourse for unfair dismissal; she would instead accept a one-off payment that would be "fair" according to the Gubskiis' discretion and Muriel's service. I, meanwhile, would receive my "fair" return for service rendered, according to the rank of 0xbridge-educated tutor.

The Gubskiis also betrayed a soslovie mindset in their appraisal of current Russian politics. They had a deep antipathy toward Aleksei Naval'nyi and his Fund to Fight Corruption: echoing Kordonskii, they said that accusations of corruption misunderstood the nature of Russia's real problems. The solution to the latter, they claimed, would be found within the All-Russia People's Front (Obshcherossiiskii narodnyi front). The front was convened in 2012 by President Putin to provide a societal forum that brought together nonpartisan representatives of various public associations and interests groups to act collectively as a faster, more responsive channel between people, party (the pro-Putin United Russia), and president. The front convened various regional forums under the banner of "Truth and Fairness" (Pravda $i$ spravedlivost'). These events, which represented unity-in-diversity by gathering together the leaders of industry and church, youth, pensioners, minorities, Cossacks, and so on, looked partly modeled on the archetype of zemstvo, the post-serfdom political and conflict resolution system of the late imperial estates (Lincoln 1990).

Yet, the plausibility of Kordonskii's claim that Russians cut up the social world into sosloviia was brought home to me most forcefully by an innocuous conversation I had with Misha during one of our history lessons. We were reading Terry Deary's Horrible Histories series on medieval England and discussing feudalism when I asked Misha what a peasant was. Playfully he giggled: "You're a peasant!" “In what sense?" 
I asked him smiling. "A worker," clarified Misha. Switching into Russian I said, "Rabochii." "Yes," concurred the boy. I quizzed him further. "Because you need to work for us, ha ha!!!" he declared breaking into riotous laughter.

Misha's upbringing had already endowed him with a certain insouciance. It is unsurprising for a child born into wealth and receiving a liberal education to regard the necessity to work (for money) with scorn; this correlates with Bourdieu's central insight that educational distinction is proportionate to the distance it stakes out from economic necessity. But the way that Misha reified and personified the life of necessity into ranked groups, "peasants-workers," suggested that he viewed a world divided into ranks of different kinds of people, different by virtue of what they did and the modality of that action ("need"). It seemed that Misha ordered the people he knew, at least his tutor and his nanny, into soslovie.

\section{A ROSGAZ CITY IN THE ASIA-PACIFIC}

What if we take Misha's joke seriously and ask whether post-Soviet people educate their children intuitively into various estates. If the Gubskiis possess their particular subject position thanks to an intimate relation with Rosgaz, what about children who stand in another relation to the Russian corporation, as "workers" or as other estates, which define themselves by distance from the necessity of subordination to soslovie imperatives? What education do they receive? To address these questions I will describe some contemporary changes taking place in a Far Eastern Russian city, my primary ethnographic fieldsite where I have spent extended periods since 2009.

Bol'shoi Kamen' is a city on the Ussuri Bay, across the bay from Vladivostok, which since the 1960s has been the center for the repair and decommissioning of the Soviet Pacific Fleet of nuclear submarines. In the early 1990s orders to the city's Zvezda submarine factory dried up and wages to its striking workforce went unpaid. The factory and the city were saved from this crisis, however, when it became a major beneficiary of a signature multilateral agreement of the early post-Cold War period: the NunnLugar Cooperative Threat Reduction Treaty. Thanks to this treaty Zvezda shipyard was designated as Pacific Russia's START II submarine decommissioning and dismantling facility. Over the next 20 years Zvezda shipyard received hundreds of millions of dollars from the United States and Japan to manage the toxic legacy of Cold War nuclear buildup. It processed liquid nuclear waste from obsolescent submarine reactors.

To facilitate and secure this work, in 1997 the Kremlin locked the city into a "closed" regime: Bol'shoi Kamen' was made a ZATO (zakrytoe administrativnoterritorial'noe obrazovanie), a closed administrative-territorial formation, a status that made it the envy of the region for the generous budgetary subsidies and inputs it received from the federal center. Ordinary Russian citizens were forbidden to reside and even enter this city without a special permit approved by the security services. The "closed city" status preserved some aspects of the Soviet dispensation inside Bol'shoi Kamen' and protected it from many of the more sudden and violent post-Soviet changes: it remained a city plugged into a single well-funded city-forming (gradoobrazuiushchee) enterprise with a relatively affluent social and cultural infrastructure. 
At the height of the city's systemic crisis in 1995-1996, around 60 of the city's youth, mainly former Komsomol cadres and "culture workers," organized an autochthonous revival of "ancient" Russian Orthodox Christianity ("Old Belief"). These religious revivalists occupied a set of abandoned military barracks and turned them into a church and a monastery. This local religious community blossomed during the late 1990 s and 2000 s as the closed city inside whose border it sat stabilized. I participated in this Orthodox congregation between 2009 and 2011, when it was mainly composed of two social groups: The first was the convert cultural workers who had founded the commune, some of whom had become priests and deacons in the church and had started to have large families. The monastery was home to the second-a group of indigent men, principally ex-convicts who had joined the rigorist Old Orthodox community as they were freed from the "zone" (prison colony) during the late 1990 s and 2000s and who remained unmarried. The broader congregation also encompassed a distinct group of nonresident members, so called sportsmen, physically active men who mostly worked in the security industry in the greater Vladivostok area of southern Primorski Krai.

The structure of this congregation had an estate-/soslovie-like structure. Each secular status (culture worker, marginalized ex-con, "sportsman") corresponded to a set of hierarchically distributed and integrated religious roles: priests to culture workers, obedients (poslushniki) to ex-cons, catechumens (oglashennye) to "sportsmen." Each rank had its political-social citizenship converted into a segmented division of rights, duties, and constraints regarding work, religious commitment, and family/sex. Marginal ex-prisoners who lived in the ZATO without papers were "canonical penitents" and obedients who served the church and the priesthood and were forbidden to marry because of canonical prohibitions that they had accrued out of (mostly lustful) transgressions. Sportsmen were active "in the world" and its morally contaminating spheres of action; they used their networks in service of the community, but as unbaptized catechumens were subject to a more relaxed religious rule such that their sins of premarital relations were not punished. The priests, meanwhile, occupied the apex of the hierarchy, had large sanctified families of baptized pious children, and did not work for money in secular professions (they were also enfranchised with resident permits in the ZATO and had contacts in the echelons of the city administration). Rather than deferring ritual participation across generations (Rogers 2009), this Old Orthodox community distributed it according to estate-like status. These three ranks therefore created a spiritual division of labor that devolved into separate and mutually supporting roles and functions: workers, warriors, priests.

My work with the Gubskiis had been partially motivated by the desire to save up money to pay for an extended return field trip to Bol'shoi Kamen' in the summer of 2016. Having finished my thesis on the religious revival, I wanted to see what had changed in the five years since my departure. When I arrived, I discovered that the religious community had schismed and that many of the ex-prisoners and bomzhi (homeless men) had left, to be replaced by the rising generation of children of the priests who had founded the community. But the biggest change was to the city itself. The status of Bol'shoi Kamen' as ZATO closed city had been abolished, while on 
the site of the submarine-dismantling plant an enormous new shipyard complex was under construction. The Zvezda Shipbuilding Complex (SSK) was scheduled to become by 2022 the biggest shipyard in Russia with 7,000 workers. President Putin declared SSK as a project of national significance that would revive civilian shipbuilding in Russia and make it globally competitive with the industry powerhouses of the Asia-Pacific region, particularly South Korea.

The reason for the rapid transformation of Bol'shoi Kamen' from US State Department-funded center for scrapping nuclear submarines into a commanding industrial summit of a resurgent Russia was revealed by the type of ships that the complex would build. Jointly funded by Rosneft and Gazprombank, Russia's largest state-controlled oil company and the financial investment arm of its gas megacorporation, respectively, the new Zvezda SSK would construct Aframax oil tankers and massive 300,000-cubic-meter gas tankers to transport liquefied natural gas (LNG). Both of these classes of ships would be supplemented by a third order on the books: nuclear-powered icebreakers. The strategic aim was to exploit the oil and gas fields along the rapidly melting North Sea Route and transport the energy to the fastgrowing Asia-Pacific region.

\section{FROM CITY-FORMING TO BUDGET-FORMING EDUCATION}

The Kremlin opened up Bol'shoi Kamen' in part to let guest workers (including Chinese and North Korean) into the new shipyard construction site. But the city's liberalization also represented the introduction of a new model of economic development for the Russian Far East. Bol'shoi Kamen' did not revert from closed status simply to that of a normal Russian city; instead the closed ZATO acronym was replaced by TOR Bol'shoi Kamen', which stood for "territory of advanced development" (territoriia operezhaiushchego razvitiia). Under this exceptional new territorial and legal regime Bol'shoi Kamen' was granted a special tax rate to attract outside investment.

The 2015 law On Territories of Advanced Development stipulated that the city's development would be overseen by a "managing corporation" (upravliaiushchaia kompaniia), the Far Eastern Development Corporation (Korporatsiia razvitiia Dal'nego Vostoka), which was responsible for supervising billions of roubles in infrastructural investment. The development corporation's plan for the city quotes President Putin, for whom the priority for the Russian Far East was the "expansion of economic freedom and presenting investors with the best conditions for doing business." These latter "best conditions" included zero-percent tax on land and property and zeropercent tax on business profits for the first five years of operations. These favorable investment conditions were intended to attract "residents" who could establish enterprises in TOR Bol'shoi Kamen' via fast-tracked contracts. Despite the personified language, however, "residents" were not individuals but the legal persons of corporations. By 2018 the nine TOR "residents" were all in one way or another connected to the new SSK, like the construction companies that were building the new micro region to house incoming factory cadres. 
A precondition of the transformation of the ZATO (closed territory) into a TOR (tax-exempt territory) was that the city budget would no longer receive the large federal subsidies that had hitherto supported its social and cultural infrastructure. This subsidy composed over a third of the city's budget. City duma deputies wrung their hands over the 30-million-rouble black hole in the annual budget. The lion's share (60 percent) of this budget was allocated for education (schools, the Shipbuilding College, and the local branch of the Far Eastern Federal University [FEFU], aka "Institute"). This financial restructuring would therefore be overwhelmingly reflected in changes to the city's education sphere. The shift in economic model from a state-supported and supranationally funded closed regime to a liberalized tax haven oriented toward "private" (but more often state-corporate) investment, though specific in some ways to the history of Bol'shoi Kamen', forms part of a Russia-wide transformation of postsocialist cities. Douglas Rogers felicitously describes this switch as one from city-forming (gradoobrazuiushchie) to budget-forming (biudzhetoobrazuiushchie) enterprises (2015:209). But how is education reformatted in a city when it is converted from city-forming to budget-forming imperatives?

During my return field trip to Bol'shoi Kamen' I naturally took an interest in education. I was curious to see how the first cohort of children brought up in the Orthodox community, whom I had originally known as youths approximately of the Gubskii boys' age and a little older, were getting on five years later as they entered the upper tiers of secondary and higher education. The children I knew best were now variously distributed between the 10th and 11th grades (final years of high school), the Shipbuilding College (where students received a secondary professional education-srednee professional'noe obrazovanie), and the local branch of FEFU.

Lesha, son of church stalwarts Aleksei and Lena, was doing well at school. With a high GPA (4 out of 5) for STEM subjects (mathematics, physics, chemistry, and informatics), he was selected, together with 24 other high-achieving pupils from his year at Municipal Budget Educational Establishment Middle School No. 2, to be the second cohort selected for "Rosneft class." Over two years, Lesha and his classmates would receive specialized training in a program "school-institute-enterprise" (shkola-VUZ-predpriiatie) introduced as a "social partnership" between joint stock company Rosneft and the Zvezda Shipbuilding Complex (cf. Rogers 2015:220).

On the first day of school, traditionally known since Soviet times as the "day of knowledge," Lesha was presented with a white necktie with the logo of the Zvezda factory and a bag of Rosneft stationary. With the unmistakable resemblance of the necktie to the outfit of the Young Pioneers (a timeless form now with corporate content substituted for communist), the Rosneft class uniform underlined the functional takeover of aspects of higher education by the Russian corporation. Giving the opening address, a company representative wished the pupils luck and good grades and reminded them that "to study in Rosneft class - with prestige comes responsibility. Rosneft class - it's entry into the big team of Rosneft!" He predicted the pupils' successful entry into the Institute and added with a concluding flourish that he expected them to graduate "with an engineering specialty of future shipbuilders." Lesha and his classmates then moved into their study room that had been decorated in 
the corporate style of a Rosneft premises. During the academic year the Rosneft pupils, along with immersion in STEM subjects, enjoyed various excursions, professionalization seminars, and team-building exercises. Regular trips were made to the SSK for liaisons with its workforce, and business game simulations were held by video link with other Rosneft classes around the country, which simulated various logistical scenarios such as ameliorating supply-chain disruption.

The local branch of the university was meanwhile gearing up for an even closer collaboration with Rosneft and Gazprom. The Far Eastern Federal University had signed agreements with Rosneft and Gazprom with the aim of tightening their "social partnership." The first step was to set up in the university's branch the Rosneft Center of Professional Competencies for instruction in skills that were "required by the business." While this venture was billed as "a mutual cooperative partnership" in which the educational institution would be treated as an equally entitled (polnopravnyi) partner vis-à-vis the corporate sponsor, the plan looked unmistakably weighted towards the demands of Rosneft. The program goal was explicitly to "produce needed market-competitive [vostrebovannye, konkuretntosposobnye] graduates for our base partner and the dictates of the work market." After all, the founding document stated: "Corporations are now the main customers [zakazchiki] for the specialists they need and require."

The rector added that the introduction of the social partnership program compelled adaptation from instructors who would need to "acquire the skill to pedagogize the idea, expressed by the customers of the educational service [zakazchikami obrazaovatel'nykh uslug]." The new educational format would have students and Rosneft, Gazprom, the Zvezda factory, or other corporate sponsors sign contracts, as a result of which social partners would finance the student's place at the university. This dyadic relation between students and their education's corporate patron fully harmonized with the new stress that university administrators placed on a "human capital" approach, a theme on which many of them spoke that year at the conference on the city's development. To enhance their competencies and self-capital, Bol'shoi Kamen' students were required to participate in World Skills, the worldwide championship for vocational occupational that promotes "a parity of esteem" between academic and vocational education.

It is no surprise that in a military-industrial monocity the education system has a vocational bent that is coupled to the needs of industry. The educational route to the factory and life employment in industry was a prestigious career route for youth in the Soviet times. Even in the post-Soviet period the local press still lauded individual workers and engineers for heroic lifelong service. There were whole dynasties of such udarniki (shock workers). But thanks to its rich cultural infrastructure (three theaters, two Palaces of Culture) Bol'shoi Kamen' provided its youth, if it was so inclined, with a basis to pursue careers less instrumentally subservient to the requirements of the factory, in culture and the arts.

The above-cited documents that legislated the new educational "social partnership" implied a structuration of students' educational preferences and choices different from those that prevailed under the closed regime. Soviet social spaces like 
Bol'shoi Kamen' were governed by an "urban regime of need fulfillment": needs were defined by norms set in a teleological system of planning (Collier 2011). Before, the city "needed" two types of youth that it ordered the educational sphere to produce: a steady supply of cadres for the factory and employees for the social-cultural sphere who would fulfill the city's equivalent sociocultural "needs," including teaching.

The cluster of words "need," "needed," and "requirement" has a cultural inflection that is difficult to fully translate (vostrebovannost', nuzhno, trebovanie). According to multiple ethnographic studies, the notions of "being needed" (Parsons 2014) or "needed by nobody" (Höjdestrand 2009) became master signifying terms for postSoviet trauma. The social partnership added another level of semantic and conceptual complexity to this terminology. Now students would need to be needed (vostrebovannye) in a field of necessity and superfluousness subtended by corporate imperatives. It is not that students would be presented with a choice between a track directed toward the factory and one leading elsewhere; rather, through a restructuring of the funding streams, the latter option would be eliminated or become rarer or be merely the preserve of those already endowed with cultural capital, as the jobs in the cultural sphere dwindled because of the cuts in the social budget.

Between 2015 and 2018 the educational sphere of Bol'shoi Kamen' was undergoing a radical reform that can fairly be called neoliberal, notwithstanding the uses and abuses of this term. The state-supported closed city-forming funding regime that provided almost half of the educational budget was winding down; the budget-forming corporation that was supposed to make up the budget shortfall, because of the clauses in the investor beneficial TOR agreement, would not need to pay taxes until the late 2020s. In the decade-long interim, the stopgap would be filled by corporate "social partnership." Bol'shoi Kamen' could be considered an experimentum crucis, a kind of counterfactual time machine for how neoliberal reform might have happened in Russia had it circumvented the debacle of shock therapy. Here was a city in which the integrated Soviet social and industrial networks had survived by the bonanza of post-Cold War global threat-reduction funding. The state was now attempting to convert this preserved productive capacity toward capturing a share of a global market of national significance, namely in hydrocarbon commodities. The youth of this city were the subjects of this experiment by which geopolitical competition was translated into the competition in the school curriculum.

The local teachers and lecturers were bracing their students for the new situation. The assistant director of the university branch opened her talk at the regionwide methodological seminar with the title "New Actualites for Students of Secondary Professional Education" thus:

It's about time that everyone got used to the inevitability of the constant changes that affect every sphere of human activity. The future is coming so fast that it leaves no space for the present, let alone the past. Something once said by one of the modern greats comes to mind: "superfluous information can be harmful." How to understand this? It means one needs to free oneself from obsolete, that is, non-necessary [nenuzhnaia] information. 
Yet, even students who completed all the requirements of their education at the Institute were far from sure that they would fall into the category of "needed" rather than "superfluous." The student newspaper reported the findings of the 2017 study "The Monitoring of the Work Placement of Graduates from the Affiliate Branch of FEFU." This survey of graduate destinations conceded that it was difficult for graduates to find work according to their specialty: only 26.19 percent of students found work "by profiled specialty" (profil'no), which was shorthand for work in the factory.

A further sociological survey inquired into the subjective effect of this objective uncertainty about whether students would be "needed" after graduation. Of the 150 respondents to the survey on "the situation of being without alternatives in questions of work" (bezal'ternativnoe polozhenie $v$ voprosakh trudoustroistva), only a quarter of respondents wanted to work in the factory, that is work in the professional sphere for which they were being trained at the Institute (a number that uncannily mirrored the average number of those who could and did find work there). Instead, over a third of respondents wanted to "do their own thing" (zanimat'sia svoim delom). By admitting to this vague goal many Bol'shoi Kamen's students seemed to be adapting their preferences to the increased competition and objectively diminishing chances that they would be needed by the city factory.

The way that students' options were increasingly foreclosed, hedged, and co-opted by the new necessities of corporate-funded tax-liberal Bol'shoi Kamen' seems to indicate a shift in what Max Weber (1978) would call the city's "mode of domination." If in the Soviet and post-Soviet closed dispensations educational choices were more often than not extracted from young people by the legitimately authoritative legalbureaucratic channels of the city-founding enterprise (quotas, norms, etc.), then the new regime overdetermined young people's opportunities by a less obvious "constellation of interests" (Weber 1978:941-948). This new regime produces an educational field warped by the overwhelming market imperatives of Russian corporations, which are engaged in rapacious geopolitical competition. While this is manifested at the ground level as a seemingly open meritocratic competition for a few spots on an elite educational track, it in fact self-selects "talented kids," those few youth who already have significant social capital (already are members of worker-aristocracy families or possess informal patrons and blat [Ledeneva 2006] networks). Sociologist Anton Oleinik (2017) has argued convincingly that the "constellation of interests" defines the anatomy of "Russian power" as it is exercised under Putin.

Yet, the constellation of interests not only takes the form of a bald encounter between market giant and the naked individual but constellates along socially stratified grooves. It is interesting to see how one identifiable group of the city's youth have availed themselves of the new corporate educational opportunities and adapted to their constraints: the first cohort of children from the Old Orthodox community. An original motivation for the formation of this religious community in the mid1990s during the city's systemic crisis was to create a place and an occupation for a group whose skills were neither needed by the factory nor obviously usable in the shadow-criminal economy that metastasized throughout post-Soviet Primorkii Krai. This identifiable caste of "culture workers" received a liberal education in the 1980s 
and were tasked during perestroika with the "humanization" of late Soviet education. The latter process entailed the introduction of more creative, student-centric approaches to learning that moved away from rigid Makarenko-style ${ }^{2}$ pedagogies. The aim of these reforms was to diversify educational outcomes away from ones slavishly subordinate to the needs of the military-industrial complex, which had hitherto been the norm in Soviet monocities.

The charismatic archpriest leader of this Old Orthodox community had been educated at the Khabarovsk State Institute of Arts and Culture during perestroika. He claimed that entering the priesthood was a continuation of his first vocation as a culture worker, a rare achievement during the "wild" 1990s when such professions were increasingly disappearing. Of his classmates at the Institute of Culture the priest boasted that only he and his wife were still engaged in creative pursuits through performing ancient monoharmonic chant, painting icons, or publishing prayer books. The archpriest and his lay colleagues in the religious revival considered themselves a class apart from the average residents of Bol'shoi Kamen'. In Soviet jargon they claimed self-deprecatingly to belong to the "rotten intelligentsia" (gnilaia intelligentsiia), a term, used ironically, ${ }^{3}$ that captured the opprobrium in which such a group was held in the Soviet hierarchy of estates that elevated above all the industrial proletariat and the party elite. These non-laborers who served Soviet society's "nonmaterial" needs were ideologically anomalous and perhaps envied for their occupational distance from factory work; resentfully tolerated, the rotten intelligentsia's freedom from manual labor could lead to accusations of "parasitism" (tuneiadstvo).

The post-Soviet children of the Bol'shoi Kamen' religious revival were reasonably successful academically: several had received Rosneft stipendiums. But this young generation carved out a more bespoke niche in the nascent corporatized higher education. The archpriest's two eldest sons, Elijah and Sergei, had founded and chaired the Institute's Student Scholarly-Scientific Society (studencheskoe nauchnoe obshchestvo). This organization encouraged students to undertake independent scholarly research, not necessarily of a strict STEM or natural-scientific variety. The aforementioned sociological survey on the attitudes to alternative kinds of work, for instance, had been organized by the student scholarly society. The priests' children had already distinguished themselves by participating in conferences and had scientific publications to their names while still in high school or in the first years at the Institute. ${ }^{4}$ Elijah and Sergei received kudos from the Institute's director for the time-

2 Anton Semenovich Makarenko (1888-1939) is generally regarded as the "father" of Soviet education. His theories and principles were strongly focused on adults as exemplars and nurturers of the "collective" imperative of pedagogy.

3 See Yurchak (2006:249) on stiob, the ironic tone characteristic of late Soviet discourse.

${ }^{4}$ Topics that they wrote on included ecological problems (the changing sex distribution of sea cucumbers, the shifting population of water beetle Charybdis japoinis) local history (from late Soviet subcultures to the history of their own community and faith), and proposals for economic and urban development (tourism, "smart cities"). They even compiled a dictionary of new internet slang that received coverage in nationwide-circulating weekly Arguments and Facts. 
liness of their initiative. Rosneft had only just made scientific-research work (nauchno-issledovatel'skaia rabota) an essential requirement for those who wished to enter their program, which de facto meant that research became obligatory for all students.

Elijah, upon graduating from the Institute, did not end up in the shipyard; instead he converted the contacts and skills he had garnered during his scholarly activism into a job as correspondent for the factory newspaper, while he pursued a second higher education-he was training to become an archivist. His younger brothers and sisters (both god-siblings and those by blood) were mostly pursuing similarly diverse paths that led away from the necessity of factory labor. None of the new generation of Old Believers had yet expressed a desire to pursue a religious vocation. But these career trajectories bore out the archpriest's view that a non-factory, intellectually involved job was structurally homologous with the priesthood, insofar as both afforded a certain status and freedom.

The priesthood was a famously cohesive estate (soslovie) in imperial Russia. At the twilight of the ancient regime the clergy produced many radical intellectual "secular sons" who rose to prominence in the early Soviet period (Manchester 2008). The conversion of "rotten intelligentsia" culture workers into post-Soviet priests resembled an attempt to reverse engineer this clerical estate out of a redundant Soviet form. The post-Soviet Orthodox priesthood certainly appeared to occupy a special rank in the crystallizing structure of the soslovie society of which Kordonskii writes. Bol'shoi Kamen"s archpriest held a seat in the Civic Chamber (Obshchestevnnaia palata) of Primorski Krai, a cross-sectional societal forum for the Maritime Region that was structurally analogous to the People's Front that so enthused the Gubskiis. The archpriest's status was also bolstered by holding the rank of captain (esaul) in the Ussuriisk Cossack Troop. Such an elevated status justified the "fair" distribution of resources within the congregation, whereby the community ought to supply the means to support the archpriest's seven children and six godchildren without the cleric making recourse to wage labor, while monastery-bound obedients were spiritually directed to remain unmarried and labor in the collective for the sake of these holy families.

But despite this internal differentiation and religious legitimation of financial and sexual inequality, everyday life within the monastery when I lived there in 20092011 was egalitarian and complementary: brothers in the faith labored together. By 2016, however, several of the older stalwarts were gone and youths such as Sergei and Elijah had moved in. Often preoccupied with the burden of their studies, these new inhabitants were sometimes less than sedulous in carrying out their chores, much to the chagrin of the monastery's foreman of two decades, Sasha. After the usual backbite that followed an uncleaned dinner table, I was surprised by a comment made by Elijah, which was spoken in a register that clearly held me in confidence as an intellectual fellow traveller. Sasha and the rest of the men were "good workers," said Elijah, in a desultory way, with the implication that they were good for work and little else. I was a little shocked by this statement because I knew Sasha to be held in the highest esteem by all of the congregation for his piety and monastic 
rigor and that the priests' children often called him "uncle Sasha." And yet it was clear that Elijah was far from regarding Sasha as an equal; to him, he was a mere "worker."

The tone in which he uttered that word with its import of subordination and enslavement to necessity, unmistakably echoed what Misha had said back in England (the peasant-worker gibe). Both Misha and Elijah, differences of upbringing and situation notwithstanding, seemed to see the world involuntarily through the lens of soslovie. Each enjoyed the advantage of a certain skholè, "scholastic distance from urgency and necessity" (Bourdieu 2000:109); each occupied a relatively privileged position in a hierarchy of estates by birth and education, via which they were insulated from need to be needed, from "vostrebovannost"'; and each owed these advantages, in the last instance but via several proxies, to a certain relationship that they had or had built to the Russian corporation.

\section{CONCLUSION: META CONNECTIONS AND FREEING THE TRUST FROM THE CORPORATION}

But the connection between Misha and Elijah is closer than simply a certain privileged subject position. Their deeper imbrication is indexed by the very link that joins them together, namely, myself. The ability of corporations to shape education and academic knowledge appears so deep that it is in fact the condition of possibility of this academic article in a way that curiously overdetermines and conditions both its ethnographic subject and object. My scholastic distance was also an illusory subject effect facilitated by the Russian corporation.

Gleb Gubskii held the position of director of Rosgaz's Marketing and Trading, the branch of the business that implemented the corporation's global LNG business strategy, including its Shipping and Operations wing. Gleb was therefore actually in charge of the "building, chartering, vetting and operating of Rosgaz's LNG shipping fleet." While I cannot confirm whether Gleb was personally involved in the Zvezda Shipbuilding Complex project, according to his formal role Gleb himself would have ultimately signed off on the big operational decisions to order LNG tankers from Bol'shoi Kamen', which resulted in the construction of this shipyard. Gleb, whose red 50-pound notes funded my 2016 research field trip to Bol'shoi Kamen' (and so the research which made this article possible), also formed the very object of study, the shifting assemblage of education, state, and corporation as it translated into the everyday experience of local youth in Bol'shoi Kamen' about which I write. The money that paid for my research, that paid for Elijah's and Sergei's non-factory jobs, that paid for Misha's elite education formed a skein of involuted complicity with the Russian corporation, an ethical position outside of which and from which to make judgments seems impossible to locate.

Is this convolution of subject and object just a coincidence that self-reflexive anthropologists love to puzzle over? I would rather argue that it shows the determining force of the Russian corporation at a deep level of causality. The tentacles of corporations are so multiplex, their reach is so long that they can "metacoordinate" 
(Rogers 2015:149) actions and project in ways of which actors are often unaware. This imbrication also appears to bring 0xbridge and Bol'shoi Kamen' symmetrically onto a plateau of global connection, which in turn makes this narrative an ethnography of global connections brought about by the unintended metacoordinating effects of the Russian corporation, which spill far beyond Russia.

Just as we looked from the vantage point of the Gubskiis and Regent's College at Bol'shoi Kamen' and its transformation, so now I believe we go full circle and return with new eyes on $0 x$ bridge education. The attempt to metacoordinate student choices in Bol'shoi Kamen' toward the market-driven agenda of hegemonic energy corporations, toward an exclusive vocational focus, looks a world away from those scholars coddled away in the ivory tower. There is a clear double standard whereby the Russian elite educates its children in the ways of nonvocational scholastic learning at ancient institutions, while it incentivizes the children in the factory towns that it runs to abandon such aspiration, which flourished during Soviet times. Ironically, then, an 0xbridge college resembles less the open, neoliberalizing Bol'shoi Kamen' than the city under the closed regime, since both the closed city and the college provided an integrated and embedded, multipurpose and nested collective. The $0 x-$ bridge college gives its members a "roof" (krysha) for protection, an integrated social shield that, when all means are exhausted, can still be fallen back upon as a last resort (ask the impoverished PhD student sleeping on a couch in the graduate suite whose swipe card provides him with a roof over his head). Such survival strategies of precarious students can be compared to the ex-cons and homeless who gravitated toward the closed city where they could cleave to a vestige of a Soviet style collective from which they had been excluded (Humphrey 2001).

Far from a hyperrational institution guided by aggregate market signals from its student consumers, the 0xbridge college still maintains the titular remnant of a feudal estate system, perhaps one of the last closeted spaces in England where feudallike distinctions can still occasionally trump the dominance of money. There is ample ethnographic evidence that Regent's College has a series of estates and produces a soslovie-style thought, both from the top and bottom of the hierarchy. My landlady Muriel not only talked of the haughty attitude of Katia. Her prior work at the college and in the chapel also furnished her with experiences of being lorded over. She jokingly referred to the college fellows, and especially the chapel choirmaster, as "the Gods" for their superior attitude and conceit that they were somehow different kinds of people from nonacademic college staff. From the other end of the hierarchy, one of the college's longest-standing and most distinguished fellows once described in an interview how his relationships to the college, from undergraduate to emeritus fellow, had been more akin to one of "feudal dependence" than that of waged academic employment, with the consequence that his ties to this "feudal" institution had been much "more menial and more intimate" than would have been the case had he worked in private enterprise (since the fellow is a world-leading theorist of politics, one should take seriously his usage of "feudal"). It was at such "feudal" institutions that the Russian corporate elite wished to have their children educated into a free and liberal attitude to socially determined necessity. 
The concluding irony appears when one specifies more accurately exactly what kind of educational institution the establishment to which the Gubskiis send their children is. Regent's College is-and its envied academic independence is guaranteed by virtue of its status as-a corporation. F. W. Maitland, the great historian of English law, showed how the masterstroke of the English medieval church jurists, which saved the country from the perils of despotism and revolution to which the continent succumbed, which enabled the realm to incubate a culture of democracy and capitalist enterprise independent from the state, was to give birth to a legal form that is both the ancestral progenitor of the modern joint stock corporation (such as Rosgaz) and Regent's College. The "unincorporated body," or "the trust," allowed people to vest lands and property in perpetuity "without troubling the state to concede or deny the mysterious boon of personality." By way of the trust the English "made corporations without troubling king or parliament" (Runciman and Ryan 2003:59). Charitable trusts such as Regent's College and its choir school are corporations that, at least until recently, were subject to no state oversight whatsoever; their only concession to bureaucratic supervision was token registration with the Charity Commission of England and Wales (stipulated by the Charitable Trusts Act of 1853). Maitland showed how the corporate form secured the "liberty of action and experimentation" (97), on which institutions of learning such as Regent's College historically depended. The corporate form, by legally personifying the continuance of funds and lands, also insulated education from fluctuations of the market (Regent's did very well during the Great Depression with its bursar, a world famous economist, investing college funds in Picassos and Braques).

This comparison discloses how the particular bundling of market, corporation, and state in the Rosneft-Bol'shoi Kamen' "social partnership" is a historically contingent grafting of disparate elements. These contingent ties can be undone, and the corporate form redeployed as a means to counter, distance, and protect precarious young people from the twin pincers of market and state. The corporatization of education therefore has two meanings: one to protect from "necessity," often in paternalistic, closed, and quasi-feudal guises, as in life as "rotten intellectual" caste; another opposite significance that in Maitland's terms constitutes "modern absolutism" (and, one may add, market fundamentalism), which exposes the "absolute individual" to the "absolute state" (Runciman and Ryan 2003:66) and the constellated rigged interests of the total global market.

When that meeting becomes the absolute digital state facing the isolated online individual, the remaining marginal spaces "outside and beyond" (vnye in Alexei Yurchak's terms [2006:126-157]) left for education appear to shrink or disappear altogether. Residents of Bol'shoi Kamen' fear that the city's experiment with COVID-19induced "distance learning" (distantsionnoe obuchenie) has hastened the Russian state's divestment from the educational sphere, the creeping retreat from as well as the corporate involvement in which this article has explored at length. Yet, "rotten intellectuals" have resisted distance learning with a critical vocabulary and theoretical awareness that resemble a local critique of neoliberal governmentality. The city's chief spokesperson for this estate, the archpriest, clearly understands that technolo- 
gies of governing and "empowering" individuals are also strategies for devolving and displacing structural risk onto their backs (Barry, Osborne, and Rose 2013; Cruickshank 1999). While the archpriest might use in his social media jeremiad, from which I quote below, the apocalyptic-sounding conspirological phrase "total globalization," rather than neoliberalism, the analytical import is similar to more academic theories:

The state is shifting the burden of responsibility for failure to complete the curriculum onto parents and their children.... I believe we are witnessing the start of a structural adjustment in the societal arrangement, the world rulers' [sil'nykh mira sego] attempt to implement the plan of total globalization.

Should this attempt succeed, claims the archpriest, a Ballardian dystopia of educational futures awaits, in which a small group of rich and powerful have their educational needs met by "elite schools and elite tutors," while the rest are abandoned to the digital scraps. The polysemous epithet used to personify those at the top of the estate educational hierarchy, sil'nye mira sego, ${ }^{5}$ whose untranslatability indicates a semiotically Russian place in the topography of power, suggests that sosloviethinking can be turned into a language of critique and turned against those who benefit from its real-world effects.

In the future, if the whole nation is transferred to distance learning and traditional schools are available exclusively for payment, the oligarchs and those in power will find the money for elite schools and elite tutors. And the children of the bulk of the country's citizens? Will they be able to get an education through a computer? Of course not. But for these masters of the universe [sil'nykh mira sego] the bulk of the population does not need to be educated.

\section{REFERENCES}

Barry, Andrew, Thomas Osborne, and Nikolas Rose. 2013. Foucault and Political Reason: Liberalism, Neo-Liberalism and the Rationalities of Government. London: Routledge.

Bourdieu, Pierre. 1984. Distinction: A Social Critique of the Judgement of Taste. Cambridge, MA: Harvard University Press.

Bourdieu, Pierre. 2000. Pascalian Meditations. Palo Alto, CA: Stanford University Press.

Collier, Stephen J. 2011. Post-Soviet Social: Neoliberalism, Social Modernity, Biopolitics. Princeton, $\mathrm{NJ}$ : Princeton University Press.

${ }^{5}$ A neutral translation would be "world leaders"; one that captures the contemporary posttruth conspiratorial overtones would perhaps be "the illuminati," though this fails to convey the religious connotations of a corrupt and illegitimate secular power that stands in contradistinction to the legitimate divinely sanctioned power that Saint Paul refers to in his 13th epistle to the Romans (13:1) (in English "the powers that be"). An important Soviet resonance is the Russian translation of the title of the 1958 French film Les grandes familles (The Great Families, known in English as The Possessors). The term is found frequently, and was probably coined within nineteenth-century Russian literature, wherein Leo Tolstoy, Nikolay Gogol, Aleksandr Ostrovskii, and others use it to refer to a distant moneyed aristocratic elite. I have used poetic license in order to convey the ironic and denunciatory sense of the phrase in the above usage by electing to translate the term as "masters of the universe." 
Cruikshank, Barbara. 1999. The Will to Empower: Democratic Citizens and Other Subjects. Ithaca, NY: Cornell University Press.

Fitzpatrick, Sheila. 1993. "Ascribing Class: The Construction of Social Identity in Soviet Russia." Journal of Modern History 65(4):745-770.

Getty, J. Arch. 2013. Practicing Stalinism: Bolsheviks, Boyars, and the Persistence of Tradition. New Haven, CT: Yale University Press.

Gilliard, Pierre. 1921. Thirteen Years at the Russian Imperial Court: A Personal Record of the Last Years and Death of the Czar Nicholas II and His Family. Translated by F. Appleby Holt. London: Hutchinson.

Höjdestrand, Tova. 2009. Needed by Nobody: Homelessness and Humanness in Post-Socialist Russia. Ithaca, NY: Cornell University Press.

Humphrey, Caroline. 2001. "Inequality and Exclusion: A Russian Case Study of Emotion in Politics." Anthropological Theory 1(3):331-353.

Humphrey, Caroline. 2002. The Unmaking of Soviet Life: Everyday Economies after Socialism. Ithaca, NY: Cornell University Press.

Humphrey, Caroline. 2012. "Inequality." Pp. 302-319 in A Companion to Moral Anthropology, edited by Didier Fassin. Malden, MA: Wiley Blackwell.

Humphrey, Caroline. N.d. "The Chamber of Fairness and Russia's System of Social Estates." Unpublished manuscript.

Kordonskii, Simon. 2008. Soslovnaia struktura postsovetskoi Rossii. Moscow: Institut Fonda “Obshchestvennoe mnenie."

Ledeneva, Alena V. 2006. How Russia Really Works: The Informal Practices that Shaped Post-Soviet Politics and Business. Ithaca, NY: Cornell University Press.

Lincoln, W. Bruce. 1990. The Great Reforms: Autocracy, Bureaucracy, and the Politics of Change in Imperial Russia. DeKalb: Northern Illinois University Press.

Manchester, Laurie. 2008. Holy Fathers, Secular Sons: Clergy, Intelligentsia, and the Modern Self in Revolutionary Russia. DeKalb: Northern Illinois University Press.

Oleinik, Anton. 2017. Market as a Weapon: The Socio-Economic Machinery of Dominance in Russia. London: Routledge.

Parsons, Michelle A. 2014. Dying Unneeded: The Cultural Context of the Russian Mortality Crisis. Nashville, TN: Vanderbilt University Press.

Rogers, Douglas. 2009. The Old Faith and the Russian Land: A Historical Ethnography of Ethics in the Urals. Ithaca, NY: Cornell University Press.

Rogers, Douglas. 2015. The Depths of Russia: Oil, Power, and Culture after Socialism. Ithaca, NY: Cornell University Press.

Runciman, David, and Magnus Ryan, eds. 2003. Maitland: State, Trust and Corporation. Cambridge: Cambridge University Press.

Sahlins, Marshall. 1994. "Cosmologies of Capitalism: The Trans-Pacific Sector of 'the World System."' Pp. 412-455 in Culture/Power/History: A Reader in Contemporary Social Theory, edited by Nicholas B. Dirks, Geoff Eley, and Sherry B. Ortner. Princeton, NJ: Princeton University Press.

Schimpfössl, Elisabeth. 2018. Rich Russians: From Oligarchs to Bourgeoisie. Oxford: Oxford University Press.

Weber, Max. 1978. Economy and Society: An Outline of Interpretive Sociology. Vol. 2. Berkeley: University of California Press.

Weber, Max, 2001. Wirtschaft und Gesellschaft: Die Wirtschaft und die gesellschaftlichen Ordnungen und Mächte. Vol. 2. Religiöse Gemeinschaften. Edited by Hans G. Kippenberg, Petra Schilm, and Jutta Niemeier. Tübingen, Germany: J. C. B. Mohr (Paul Siebeck).

Yurchak, Alexei. 2006. Everything Was Forever, Until It Was No More: The Last Soviet Generation. Princeton, NJ: Princeton University Press. 


\section{КОРПОРАЦИЯ, ОБРАЗОВАНИЕ И ЗНАНИЕ СОСЛОВИЯ МЕЖДУ ЗАКРЫТЫМ ГОРОДОМ И ОКСБРИДЖЕМ}

\section{Доминик Мартин}

Доминик Мартин, Центр по вопросам миграции, политики и общества (COMPAS), Школа антропологии и музейной этнографии, Оксфордский университет. Адрес для переписки: University of Oxford, COMPAS, School of Anthropology, 58 Banbury Road, 0xford, 0X2 6QS, UK. dominic.martin@compas.ox.ac.uk.

Статья основана на исследовании, проведенном при поддержке Совета по экономическим и социальным исследованиям (Великобритания), Центра Макмиллана в Йельском университете (США), а также Высшей школы экономики в Санкт-Петербурге (Россия). Автор выражает благодарность Кэролайн Бенсон-Холл, Кэролайн Хамфри и Дагу Роджерсу, а также двум анонимным рецензентам за ценные замечания к статье.

Возникновение современных корпораций в путинской России совпало с возрождением сословности - формы социального сегментирования, в основе которой лежат не клановые, племенные или классовые различия, а «кастовость». В своей теории социальных различений Пьер Бурдье выделяет особо важную роль образования, особенно подчеркивая дистанцированность от экономической нужды как характерный идеал буржуазных образовательных устремлений. В статье рассматриваются два современных взгляда на образование, связующим звеном между которыми выступает российская энергетическая корпорация. Первая перспектива связана с семьей, принадлежащей к российской элите и живущей в Англии, а вторая - с детьми человека, входящего в возрождающуюся группу староверов в прежде закрытом городе Приморского края. Задействуя теоретический аппарат, разработанный Бурдье, я исследую, как концепция сословий продолжает использоваться для упорядочения различных функций и слоев общества. В частности, я рассматриваю сословие как движущую силу, стоящую за различными аспектами выбора образования молодых людей, взрослеющих на противоположных социальных и географических границах сферы деятельности одной глобальной корпорации. В обоих контекстах чувство принадлежности к сословию является ключевым принципом образования. В рамках автоэтнографической перспективы я провожу связь между старинным элитным британским колледжем и прежде закрытым военно-промышленным городом на тихоокеанском берегу России. Контекст новой корпоративной властной элиты при этом наслаивается на ситуацию маргинального раскольнического религиозного сообщества на другой стороне земного шара. Устойчивое культурное наследие советских времен играет в этой общности не меньшую роль, чем недавно приобретенные буржуазные устремления.

Ключевые слова: различение; корпорация; нужда; образование; сословие 